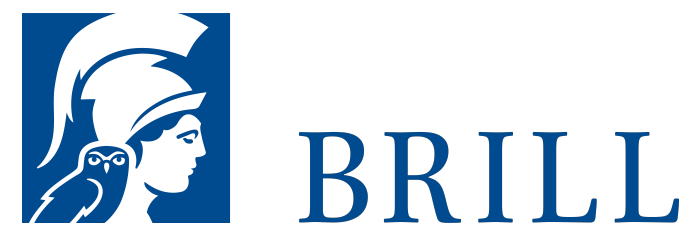

\title{
Solidarität als moralische Arbeitsteilung
}

Author: Jörg Löschke

Was ist Solidarität? Welchen Platz sollte der Begriff in unserem moralischen Vokabular haben? Gibt es eine moralische Pflicht zur Solidarität? Oder ist solidarisches Handeln supererogatorisch - also löblich und gut, ohne von Personen eingefordert werden zu können? Um diese Fragen zu beantworten, entwickelt dieses Buch ausgehend von den Theorien von Jürgen Habermas, Axel Honneth und Richard Rorty eine Solidaritätsauffassung, in der der Solidaritätsbegriff auf Hilfspflichten verweist, die Mitglieder partikularer Gruppen gegeneinander haben; das Ziel dieser Hilfspflichten besteht in der Beseitigung moralischen Missständen, die die praktischen Identitäten der Gruppenmitglieder betreffen. Dadurch grenzt sich Solidarität von anderen, verwandten Begriffen wie Mitleid, Barmherzigkeit oder Loyalität ab. Begründet wird Solidarität, indem sie als ein Prinzip moralischer Arbeitsteilung aufgefasst wird: Allgemeine Hilfspflichten werden unter bestimmten Akteuren aufgeteilt, um ungerechte Zustände möglichst effizient zu beseitigen. Solidarität verbindet in dieser Auffassung Aspekte von moralischem Universalismus und Partikularismus ebenso wie von Deontologie und Konsequentialismus.

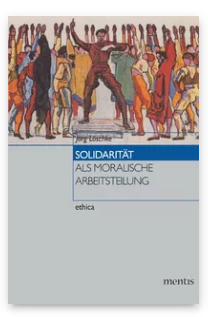

Pages: 221

Seiten

Language:

German

Subjects:

General,

Philosophy

Publisher: Brill | mentis

Series:

ethica, Volume: 30

E-Book (PDF)

Released online: 22 Jun 2015

ISBN: 978-3-

95743-919-2

List price

Paperback

Publication date: 22 Jun 2015

ISBN: 978-395743-002-1

List price 
For more information see brill.com

Order information: Order online at brill.com +44330 333 0049 | customerservices@brill.com Submission information: brill.com/authors

Titles published by Brill | Fink, Brill | mentis or Brill | Schöningh: +49(o)715413279216| brill@brocom.de 